\title{
Vitamin D Status of Pregnant Women and the Association between Vitamin D Levels and Selected Pregnancy Outcomes
}

\author{
Adinma JIB ${ }^{1}$, Nwankwo MC ${ }^{2}$, Ahaneku JE ${ }^{3}$, Ugboaja $\mathrm{JO}^{4}$, Ibe CC $\mathrm{CH}^{5}$, Edet $\mathrm{MM}^{6}$ \\ ${ }^{1,2,4}$ Department of Obstetrics and Gynecology, Nnamdi Azikiwe University and Teaching Hospital (NAUTH) \\ ${ }^{3}$ Department of chemical pathology, Nnamdi Azikiwe University
}

${ }^{5}$ Department of community medicine, Nnamdi Azikiwe University and Teaching Hospital

${ }^{6}$ Centre for health and allied legal and demographical development research and training (CHALADDRAT), Nnamdi Azikiwe University

\begin{abstract}
Background: High prevalence of vitamin D deficiency is recognized to be widespread amongst pregnant women, especially in the temperate regions of the world, and has been associated with adverse pregnancy outcomes. There is paucity of data on studies evaluating vitamin D status, and its effect on pregnancy in African population. Study objectives: This study was conducted to determine the vitamin D status of parturient women, and its relationship with selected pregnancy outcomes-fetal birth weight, placental weight, and Apgar scores at Nnamdi Azikiwe University Teaching Hospital (NAUTH), Nnewi, Nigeria. Methods: This is a pilot cross-sectional study involving 40 consecutive consenting parturient women at NAUTH, Nnewi. The subject were recruited through a convenience sampling technique. The serum of maternal blood samples collected before delivery was assayed for 25 hydroxyvitamin $D_{3}$ using HPLC system. The neonatal characteristics and placental weights were recorded in an attached proforma form. Statistical analysis of data was perform using SPSS version 21. Relationship of variables was done with Chi-square test. A p-value of 0.05 was considered to be statistically significant at $95 \%$ confidence interval. Result: The mean maternal serum 25-hydroxyvitamin $D_{2}$ was $53.2 \pm 11.3 n g / m l$. The prevalence of vitamin $D$ deficiency was $7.5 \%$, while $92.5 \%$ of the parturient women had normal maternal levels of vitamin $D$. The mean fetal birth weight was $3.3 \pm 0.5 \mathrm{~kg}$, and there was a significant positive correlation between maternal serum vitamin $D$ status and fetal birth weight $(p=0.01, r=0.560)$ Conclusion: Prevalence of vitamin D amongst pregnant women of southeast Nigeria is low. There is positive correlation between maternal vitamin $D$ status and fetal birth weight. Recommendation: There is probably no need for maternal supplementation of vitamin $D$ in pregnancy in this environment. Further research with wider and larger population may be necessary to corroborate this findings.
\end{abstract}

\section{Introduction}

Vitamin D deficiency is believed to be widespread globally and is currently recognized to be one of the most untreated nutritional deficiencies worldwide. ${ }^{1}$ Vitamin D deficiency in pregnancy has high prevalence in several part of the world where it has been studied. An Irish study reported a prevalence rate of $52.6 \%$ amongst Irish pregnant women ${ }^{2}$ while Kazemi et al. $^{3}$ reported a prevalence rate of $86 \%$ and $46 \%$ amongst pregnant Iranian women in winter and summer respectively. Studies conducted in India in $2005,{ }^{4}$ and another in $2018^{5}$ reported a prevalence rate of $84 \%$ and $88 \%$ respectively. Vitamin D naturally occurs in humans as cholecalciferol (vitamin $\mathrm{D}_{3}$ ). Primary hydroxylation of vitamin $\mathrm{D}$ to $25(\mathrm{OH}) \mathrm{D}$ occurs in the liver, while secondary hydroxylation to the active form known as $1,25(\mathrm{OH})_{2} \mathrm{D}$ occurs in the kidney, and is regulated by the circulating levels of calcium, phosphorus and parathyroid hormones ${ }^{5,6}$. Vitamin D receptors occur widespread in humans especially in endothelial and vascular smooth muscle cells, and infact in more than 30 different tissues including the pancrease, myocardium, lymphocytes, breast and prostrate. ${ }^{7,8}$ Measurement of nutritional vitamin D level of an individual is in the form of $25(\mathrm{OH}) \mathrm{D}_{3}$ rather than $1,25(\mathrm{OH})_{2} \mathrm{D}_{3}$. Circulating $25(\mathrm{OH}) \mathrm{D}_{3}$ relates directly to ultraviolet B light. On the contrary, circulating $1,25(\mathrm{OH})_{2} \mathrm{D} 3$ is controlled mainly by calcium homeostasis and is directly unrelated to one's nutritional vitamin D status. Several studies have reported that infants of mothers with low vitamin D levels have low cord blood serum levels of calcium buttressing the relationship between calcium and vitamin $\mathrm{D}^{9,10,11}$. It is therefore likely that maternal vitamin D levels affect fetal growth and bone development-explaining the low birth weight associated with low maternal vitamin D levels ${ }^{12,13,14}$. Mothers with low levels of vitamin D have been reported to give birth to offspring with reduced intrauterine and postnatal skeletal development ${ }^{15,16}$. Low level of maternal vitamin $\mathrm{D}$ has also been associated with poor Apgar score, increased risk of postpartum haemorrhage, increased risks for pre-eclampsia, and caesarean section due to uterine hypotonia. ${ }^{17,18,19}$ Although vitamin D is obtainable from various types of foods, such as oily fish and fortified margarines, the major source is the skin's synthesis of the vitamin through exposure to solar ultraviolet light. Sunshine is abundant in Africa. The thickly pigmented dark skin of the black people of Africa usually act as a sunscreen preventing the penetration of ultraviolet light expected to produce vitamin D. Vitamin D levels are therefore expected to be low amongst the black African population inspite of the abundant sunshine. The literature is deplete of studies investigating serumvitamin D levels of pregnant women in sub-Saharan Africa together with the influenceon pregnancy outcome. This study has been undertaken as a pilot,to determine the serum vitamin D levels

Volume 8 Issue 8, August 2019 


\section{International Journal of Science and Research (IJSR) \\ ISSN: 2319-7064 \\ ResearchGate Impact Factor (2018): 0.28 | SJIF (2018): 7.426}

of pregnant parturient women in South eastern Nigeria and the relationship if any with fetal birth weight, placental weight, Apgar scores and uterine atony. The findings from this study will constitute a framework for the design of a more comprehensive study on vitamin D levels involving a larger group of pregnant women from this important segment of the world population.

\section{Subject and method}

This is a pilot cross-sectional, prospective study designed to determine the vitamin D status of pregnant parturient women at Nnamdi Azikiwe University Teaching Hospital (NAUTH), Nnewi, and its influence on selected pregnancy outcomesFetal apgar scores, fetal birth weight, and placental weight.

Ethical approval for this study was obtained from the ethical committee of NAUTH and appropriate participatory consent elicited and obtained from the parturient women following appropriate explanation and counselling on the nature of the study. Relevant consultations were held with the head of department of Obstetrics and Gynaecology and other supervising consultants of the departments, together with the chemical pathologists, laboratory scientists, resident doctors, and nurse-midwives involved in the study. The study was carried out at the labour ward of NAUTH, Nnewi. NAUTH is located in Nnewi, a semi-urban town and second largest city in Anambra state, south eastern Nigeria. NAUTH is a tertiary referral hospital with 23 clinical departments with patient catchment covering upto 6 out of 36 states of Nigeria.

Serum obtained from each maternal blood sample was labelled and stored at $-80^{\circ}$ centigrade, and ultimately assayed for 25 hydroxyvitamin $D_{2}$ and $D_{3}$ using High Pressure Liquid Chromatography (HPLC). ${ }^{20}$ The proforma containing the fetal Apgar Scores, fetal birth and placental weight was completed. The data obtained (i.e assay and proforma) were appropriately coded and keyed into thecomputer. Data analysis was performed using SPSS version 21. Crosstabulation was done to explore relationship between variables. The level of statistical significance was set at $\mathrm{p}$-value of $\leq 0.05$ providing $95 \%$ confidence interval.

\section{Results}

Of the 40 parturient women studied, $37(92.5 \%)$ had normal $/$ sufficient level of Vitamin D ( $\geq 32 \mathrm{ng} / \mathrm{ml}$ or $80 \mathrm{nmol} / \mathrm{l})$, while only $3(7.5 \%)$ had abnormal/deficient levels of vitamin D $(<32 \mathrm{ng} / \mathrm{ml}$ or $80 \mathrm{nmol} / \mathrm{l})$-table $1 \mathrm{a}$.

The prevalence accordingly for the classification of maternal serum vitamin D levels into deficiency $(\leq 20.9 \mathrm{ng} / \mathrm{ml})$, insufficiency $(21-29.9 \mathrm{ng} / \mathrm{ml})$ and sufficiency $(\geq 30.0 \mathrm{ng} / \mathrm{ml})$ were $1(2.5 \%), 2(5.0 \%)$, and $37(92.5 \%)$ respectively - Table $1 b$.

The mean maternal serum vitamin D concentration was 53.2 $\pm 11.3 \mathrm{ng} / \mathrm{ml}$.-table $1 \mathrm{~b}$
Table 2 summarizes the frequency distribution of the pregnancy outcomes. The mean fetal birth weight was $3.3 \pm$ $0.5 \mathrm{~kg}$. Only one $(2.5 \%)$ fetus weighed below $2.5 \mathrm{~kg}$ (premature)while $3(7.5 \%)$ weighed $>4.2 \mathrm{~kg}$ (postmature). The remaining 36(90\%) weighed within the range of maturity $(2.5 \mathrm{~kg}-4.1 \mathrm{~kg})$.

Three $(7.5 \%)$ placentae weighed less than $0.4 \mathrm{~kg}$ while $4(10.0 \%)$ weighed greater than $0.9 \mathrm{~kg}$. The remaining 33 $(82.5 \%)$ weighed between $0.5 \mathrm{~kg}$ and $0.8 \mathrm{~kg}$. One minute Apgar score of $0-4$ occurred in only one $(2.5 \%)$ fetus; while that of 8 10 occurred in 39 (97.5\%) fetuses. No fetus had an Apgar score between 5 and $7(0 \%)$. All the fetuses $40(100 \%)$ had a 5minute Apgar score of 8-10. Uterine atony did not occur in any of the parturient women- $0 \%$.

Table 3 shows the distribution by fetal birth weight for normal and low level of vitamin D. Normal vitamin D levels occurred with increasing range of fetal birth weight $-0(0 \%)$ for fetal birth weight $<2.5 \mathrm{~kg}$, and $34(89.5 \%)$ for fetal birth weight from 2.5 to 4.1 ; and $3(100 \%)$ for fetal birth weight $\geq 4.2 \mathrm{~kg}$. Conversely, low vitamin D levels were associated with decreasing fetal birth weight- $0(0 \%)$ for birth weight $\geq 4.2 \mathrm{Kg}$; $2(5.4 \%)$ for birth weight 2.5 to 4.1 and $1(100 \%)$ for fetal birth weight $<2.5 \mathrm{~kg}$. The relationship was statistically significant (pearson chi-square value $=18.378 ; \mathrm{df}=4 ; \mathrm{P}$-value $=0.001$ ).

Table 4 shows the distribution by pregnancy outcomes for maternal serum vitamin D level correlation. Only fetal birth with showed significant correlation with maternal serum vitamin $\mathrm{D}$ (rho=0.560, $\mathrm{P}=0.01$ ). placental weight and Apgar scores at 1-minute and 5minutes show no significant correlation with maternal serum vitamin $\mathrm{D}$ levels-rho $=0.288$, $\mathrm{P}=0.158 ; \mathrm{Rho}=-0.040, \mathrm{p}=0.806$; $\mathrm{rho}=0.140, \mathrm{p}=0.388$ for placental weight, Apgar score at 1-minute and Apgar scores at 5 -minutes respectively.

Table 5 summarizes the descriptive statistics of vitamin D status and pregnancy outcomes -fetal birth weight, placental weight, one-minute Apgar score and Five minute Apgar scores with respect to number, minimum and maximum values, mean and standard deviation.

Table 1 (a): Frequency distribution of vitamin D status according to normal and abnormal/deficient levels

\begin{tabular}{|c|c|c|}
\hline Vitamin D status $(\mathrm{ng} / \mathrm{ml})$ & Frequency & Percentage \\
\hline Normal/sufficient level $(\geq 32)$ & 37 & 92.5 \\
\hline Abnormal/deficient level $(\leq 32)$ & 3 & 7.5 \\
\hline Total & $\mathbf{4 0}$ & $\mathbf{1 0 0 . 0}$ \\
\hline
\end{tabular}

Table 1(b): Frequency distribution of vitamin D status according to deficient, insufficient and normal/sufficient levels

\begin{tabular}{|c|c|c|}
\hline Vitamin D status (ng/ml) & Frequency & Percentage \\
\hline Normal/sufficient level $(\geq 30)$ & 37 & 92.5 \\
\hline Insufficient level $(21-29.9)$ & 2 & 5.0 \\
\hline Deficient level $(\leq 20.9)$ & 1 & 2.5 \\
\hline & & \\
\hline Mean vitamin (ng/ml) & $53.2 \pm 11.3$ & \\
\hline Total & 40 & 100.0 \\
\hline
\end{tabular}

Volume 8 Issue 8, August 2019 www.ijsr.net 


\section{International Journal of Science and Research (IJSR) \\ ISSN: 2319-7064 \\ ResearchGate Impact Factor (2018): 0.28 | SJIF (2018): 7.426}

Table 2: Frequency distribution of the pregnancy outcomes

\begin{tabular}{|l|l|l|}
\hline Pregnancy outcomes & Frequency & Percentage (\%) \\
\hline Birth weight & & \\
\hline$<2.5$ & 1 & 2.5 \\
\hline $2.5-4.1$ & 36 & 90 \\
\hline$\geq 4.2$ & 3 & 7.5 \\
\hline Total & 40 & 100.0 \\
\hline Placental weight & & \\
\hline$\leq 0.4$ & 3 & 7.5 \\
\hline $0.5-0.8$ & 33 & 82.5 \\
\hline$\geq 0.9$ & 4 & 10.0 \\
\hline Apgar score (1-minute) & & \\
\hline$\leq 4$ (poor) & 1 & 2.5 \\
\hline $5-7$ (good) & 0 & 0 \\
\hline $8-10$ (very good) & 39 & 97.5 \\
\hline Apgar scores (5-minutes) & & \\
\hline$\leq 4$ (poor) & 0 & 0 \\
\hline $5-7$ (good) & 0 & 0 \\
\hline $8-10$ (very good) & 40 & 100 \\
\hline & & \\
\hline Uterine atony & 0 & 0 \\
\hline
\end{tabular}

Table 3: Distribution by the association of fetal birth weight for normal and low levels of vitamin D

\begin{tabular}{|c|c|c|c|c|c|c|}
\hline \multirow{2}{*}{$\begin{array}{c}\text { Birth } \\
\text { Weight } \\
(\mathrm{kg})\end{array}$} & \multicolumn{2}{|c|}{ Vitamin D (ng/ml) } & \multirow{2}{*}{$\begin{array}{l}\text { Pearson } \\
\text { chi-square }\end{array}$} & \multirow[b]{2}{*}{ df } & \multirow[b]{2}{*}{$\begin{array}{c}\mathrm{p}- \\
\text { value }\end{array}$} & \multirow{2}{*}{$\begin{array}{c}\text { Significant } \\
\text { level }\end{array}$} \\
\hline & $\begin{array}{c}\text { Normal } \\
\mathrm{N}(\%) \\
\end{array}$ & $\begin{array}{c}\text { Low } \\
\text { N (\%) }\end{array}$ & & & & \\
\hline$<2.5$ & $0(0)$ & $1(100)$ & 18.378 & 4 & 0.001 & Significant \\
\hline $2.5-4.1$ & $34(89.5)$ & $2(5.2)$ & & & & \\
\hline$\geq 4.2$ & $3(100)$ & $0(0)$ & & & & \\
\hline Total & $37(92.5)$ & $3(7.5)$ & & & & \\
\hline
\end{tabular}

$\mathrm{Df}=$ degree of freedom

Table 4: Distribution by pregnancy outcomes for maternal serum vitamin D level correlation

\begin{tabular}{|c|c|c|c|}
\hline Pregnancy outcomes & $\begin{array}{c}\text { Pearsons } \\
\text { correlations }\end{array}$ & P-value & $\begin{array}{c}\text { Level of } \\
\text { significance }\end{array}$ \\
\hline Birth weight & 0.560 & $0.001^{* *}$ & Significant \\
\hline Placental weight & 0.288 & 0.158 & Not significant \\
\hline Apgar score (1-minute) & -0.040 & 0.806 & Not significant \\
\hline Apgar scores (5-minutes) & -0.140 & 0.388 & Not significant \\
\hline
\end{tabular}

$* *$ Correlation is significant at 0.01

Table 5: Descriptive statistics of vitamin D status and pregnancy outcomes -fetal birth weight, placental weight, oneminute Apgar score and Five minute Apgar scores

\begin{tabular}{|c|c|c|c|c|c|}
\hline $\begin{array}{c}\text { Pregnancy } \\
\text { outcomes }\end{array}$ & N & Minimum & Maximum & Mean & $\begin{array}{c}\text { Std. } \\
\text { Deviation }\end{array}$ \\
\hline Vit. D. Status & 40 & 19.2 & 68.1 & 53.195 & 11.3400 \\
\hline Fetal birth wt. & 40 & 1.8 & 4.4 & 3.267 & 0.4875 \\
\hline Placental wt. & 40 & 0.4 & 1.1 & 0.640 & 0.1516 \\
\hline One minute Apgar & 40 & 4 & 10 & 9.08 & 1.141 \\
\hline Five minutes Apgar & 40 & 6 & 10 & 9.90 & 0.632 \\
\hline
\end{tabular}

\section{Discussion}

This study reveals a relatively low prevalence rate $(7.5 \%)$ of maternal vitamin D deficiency (VDD) amongst the paturient women of this study population when compared to previous studies carried out in ireland, $56.2 \%{ }^{2}$; Iran $86 \%$ and $46 \%$ in both winter and summer respectively ${ }^{3}$; and India, $84 \%{ }^{4}$ and $88 \%^{5}$.

This prevalence rate is even lower, 2.5\% VDD when computed withthe older definition of VDD of $<20 \mathrm{ng} / \mathrm{ml}$ as shown in table $1 \mathrm{~b}$ of the result. In general, this very low levels of maternal serum vitamin D observed amongst this homogenous black population compared to the relatively very high figures reported from studies from predominantly white Caucasian and Asian population, appears paradoxical seeing in the light of the fact that the dark pigmented skin of the women in this study would have constituted sunscreen sufficient enough to prevent the availability of the needed ultraviolet sunrays for the endogenous production of vitamin D. Sunshine in Africa is abundant and it is tempting to suggest that the intensity of sunshine might be playing a superiority role than the degree of skin pigmentation with respect to the availability of the necessary rays for the production of vitamin D. It is also possible that other unconfirmed variables such as place of domicile, local diet, occupation, and clothingsmay play a role in the overall availability of vitamin $\mathrm{D}$ in this study population.

This study further revealsa significant positive correlation $(\mathrm{P}=0.01)$ between maternal serum vitamin $\mathrm{D}$ status and fetal birth weight. The newborns of mothers with normal and high levels of serum vitamin D had higher birth weights than those of low levels. Maternal serum vitamin D values were therefore lowest in low birth weight infants $(<2.5 \mathrm{~kg})$ and highest in macrosomic infants $(\geq 4.2 \mathrm{Kg})$. The findings in this study corroborate the report from two studies carried out by Marya et al. ${ }^{12,21}$ which clearly revealed the beneficial effect of maternal vitamin D supplementation on fetal birth weight, although another report from Zhila et al. ${ }^{22}$ did not show any significant correlation between maternal serum vitamin D status and fetal birth weight.Studies have reported the link between low maternal vitamin D levels and low cord blood calcium, ${ }^{9,10,11}$ as a plausible explanation of the relationship between low maternal serum vitamin $\mathrm{D}$ levels and low infant birth weight. Mothers with low levels of serum vitamin D invariably give birth to offspring with reduced intrauterine skeletal development that ultimately result in low fetal birth weight ${ }^{15}$.

In contradistinction to studies that have reported a correlation between low levels of maternal serum vitamin D and low Apgar scores, there is no significant correlation between maternal serum vitamin $\mathrm{D}$ and the other variables of pregnancy outcomes, Apgar score inclusive. ${ }^{17,18,19}$ In this studythe only baby with poor one-minute Apgar score of 4 was due to fetal distress following events of labour. None of the paturient mothers haduterine atony or primary postpartum haemorrhage, irrespective of vitamin D status -low or normal as opposed to previous report. ${ }^{17,18,19}$ It is possible that the low number of parturients studied may be responsible for this difference. The low prevalence of Vitamin D deficiency observed in this study obviously indicate that maternal vitamin D supplementation in pregnancy as practiced in some countries may not be necessary in the pregnant women in this

Volume 8 Issue 8, August 2019 


\section{International Journal of Science and Research (IJSR) \\ ISSN: 2319-7064 \\ ResearchGate Impact Factor (2018): 0.28 | SJIF (2018): 7.426}

study area. Pregnant women may instead benefit from advice and encouragement on adequate exposure of their body (skin) to sunlight, especially for those holding indoor occupation.

However, further research may be necessary to study the influence of social, environmental and dietary factors on vitamin D status during pregnancy in this study environment.

Apart from the positive correlation that exist between vitamin D levels and infant birth weight, none of the other delivery outcome variables showed any correlation with low vitamin D levels. There may therefore be no need for maternal supplementation of vitamin D during pregnancy in this study environment.

\section{References}

[1] Van Schoor NM, Lips P. World wide Vitamin D status. Best practice and research clinical Endocrinology and Metabolism. 2011; 25:671-680.

[2] O'Riordan MN, Kiely M, Higgins JR, Cashman KD. Prevalence of suboptimal vitamin D status during pregnancy. Ir Med J. 2008 Sep; 101 (8): 240, 242-3.

[3] Kazemi A, Sharifi F, Jafari N, Mousavinasab N. High prevalence of vitamin D deficiency among pregnant women and their newborns in an Iranian population. J Women's Health (Larchmt). 2009 Jun; 18(6):835-9.

[4] Sachan A, Gupta R, Das V, Agarwal A, Awasthi PK, Bhatia V. High prevalence of vitamin D deficiency among pregnant women and their newborns in Northern India. Am J Clin Nutr 2005; 81: 1060-4

[5] Dipali P, Smita, Kalpana S, Swet N. Vitamin D in Pregnancy and its Correlation with Feto Maternal

[6] Outcome. International Journal of Contemporary Medical Research. 2018;5(1):1-5.

[7] Christakos S, Ajibade DV, Dhawan P, Fechner AJ, Mady LJ.Vitamin D: Metabolism. Endocrinol Metab Clin North Am. 2010; 39:243-53

[8] Zehnder D, Bland R, Williams MC, McNinch RW, Howie A J, Stewart PM, et al. Extra renal expression of 25-hydroxyvitamin D (3)-1 alpha-hydroxylase. J Clin Endocrinol Metab 2001; 86: 888-94.

[9] Norman AW. Vitamin D receptor: New assignments for an already busy receptor. Endocrinology 2006; 157: 5542-8.

[10] Bodnar LM, Sim han HN, Frank MP, Cooperstein E, Roberts JM. High prevalence of vitamin D insufficiency in black and white pregnant woman residing in the northern United States and their neonates. J Nutr. 2007; 137:447-452

[11] Congdon P, Horsman A, Kirby PA, Dibble J, Bashir T. Mineral content of the fore arms of babies born to Asian and white mothers. BMJ 1983; 286:1234-5.

[12] Marya K, Rathee S, Lata V, Mudgil S: Effects of vitamin D supplementation in pregnancy. Gynecol obstet invest 1981; 12:155-61.

[13] Moncrieff M, Fadahunsi TO. Congenital rickets due to maternal Vitamin D deficiency. Archives of Disease in childhood 1974; 49:810-811.
[14] Nozza JM, Rodda CP. Vitamin D deficiency in mothers of infants with rickets. Med J Aust 2001; 3:253-5.

[15] Mannion CA, Gray- Donald K, Koski KG. Association of low intake of milk and vitamin D during pregnancy with decreased birth weight. CMAJ 2006; 174:12731277.

[16] Pawley N, Bishop N J. Prenatal and infant predictors of bone health: the influence of vitamin D. Am J Clin Nutr 2004; (Suppl): 1748S-51S

[17] Javaid MK, Crozier SR, Harvey NC, Dennison EM, Boucher BJ, Arden NK, et al. Maternal vitamin D status during pregnancy and childhood bone mass at age nine years: a longitudinal study. Lancet 2006; 367: 36-43. Brooke O G.

[18] Sabour H, Hossein-Nezhad A, Maghbooli Z, Madani F, Mir E, Larijani B. Relationship between pregnancy outcome and maternal vitamin D and calcium intakes: A cross-sectional study. Gynecol Endocrinol 2006; 22: 585-9.

[19] Garratt F N. Pre-Eclampsia: a challenge to public health teams worldwide to ensure that maternal diet contains adequate levels of folic acid, n3 polyunsaturated fatty acids and vitamin D at conception. Public health. 2009 Jan; 123(1): 85-6.

[20] Merewood A, Mehta S D, Chen T C, Bauchner H, Holick M F. Association between vitamin D deficiency and primary cesarean section. J Clin Endocrinol metab. 2009Mar; 94(3): 940-5.

[21] Lips P. Which circulating level of 25-hydroxy vitamin is appropriate? J Steroid Biochem Mol Biol 2004; 8990:611-614.

[22] Marya RK, Rathee S, Dua V, Sangwan K. Effect of vitamin D supplementation during pregnancy on foetal growth. Indian J med Res 1988; 88:488-92.

[23] Zhila M, Arash H, Ali R.S, Farzaneh K, Farzaneh S, Madani and Bagha L. In, vitamin D status in mothers and their newborns in Iran. BMC Pregnancy and childbirth 2007; 7:1. 